\title{
Response of Pearl Millet [Pennisetum glaucum L. (R. Br.)] to Integrated Nitrogen Management
}

\author{
Poonam Kumari Yadav'*, Rajhans Verma ${ }^{1}$, J.K. Bamboriya ${ }^{1}$, \\ Suresh Yadav ${ }^{2}$ and Rajesh C. Jeeterwal ${ }^{3}$ \\ ${ }^{1}$ Department of soil science and agricultural chemistry, SKN College of Agriculture (SKNAU), \\ Jobner, 303329 Jaipur, India \\ ${ }^{2}$ Division of Genetics, IARI, New Delhi, India \\ ${ }^{3}$ Division of plant breeding and genetics, RARI (SKNAU), Durgapura, Jaipur, India \\ *Corresponding author
}

\section{A B S T R A C T}

In the present study, the integrated use of different sources of nitrogen was used to estimate the growth and yield of pearl millet. The field experiment was conducted at

\section{Keywords}

Pearl millet, Integrated nitrogen management, Vermicompost

Article Info

\section{Accepted:}

04 January 2019

Available Online:

10 February 2019
Agronomy farm, of S.K.N. College of Agriculture, Jobner (Rajasthan) during kharif season 2017 in loamy sand soil. The experiment was laid out according to factorial randomized block design with three replications. The experiment comprised eight treatments of sources of nitrogen (Control, 50\% RDN through urea $+50 \%$ RDN through vermicompost, 50\% RDN through urea+ 50\% RDN through FYM, 75\% RDN through urea+ $25 \%$ RDN through vermicompost, $75 \%$ RDN through urea $+25 \%$ RDN through FYM, 100\% RDN through urea, 100\% RDN through vermicompost and $100 \%$ RDN through FYM) and two treatments of biofertilizer (without inoculation and with Azotobacter) were applied to the pearl millet variety RHB-173. The RDN was $60 \mathrm{~kg} \mathrm{~N}$. The application of sources of nitrogen significantly increased plant height, dry matter accumulation, number of effective tillers, grains per ear, test weight, grain and Stover yield, under $75 \%$ RDN through urea+ $25 \%$ RDN through vermicompost and seed inoculation with Azotobacter significantly increased plant height, dry matter accumulation, number of effective tillers, grains per ear, test weight, grain and stover yield.

\section{Introduction}

Pearl millet [Pennisetum glaucum (L.) R. Br. emend Stuntz] is one of the important millet crop of arid and semi-arid climatic condition. It is grown in poor sandy soil due to drought escaping character and also provides staple food in short period relatively in dry tracts of the country. It is nutritionally better than many cereals as good source of protein having higher digestibility $(12.1 \%)$, fat (5\%), carbohydrate (69.4\%) and minerals (2.3\%). Green fodder is either used as preserved hay or silage, which are extremely useful in dry regions. Pearlmillet cultivation in India is the largest producer of pearl millet having $9.1 \mathrm{~m}$ 
ha area with an annual production of $9.08 \mathrm{~m}$ tones and average productivity is $1156 \mathrm{~kg} / \mathrm{ha}$ (Anonymous, 2016-17). It ranks fourth next to rice, wheat and sorghum with respect to area, however, with regard to production, it follows rice, wheat, sorghum and maize. It is mainly cultivated in Rajasthan, Maharashtra, Gujarat, Uttar Pradesh and Haryana in our country. Rajasthan stands first in the country and produce 4.85 million tonnes from $4.09 \mathrm{~m}$ ha area with an average productivity of 890 $\mathrm{kg} / \mathrm{ha}$ (Anonymous, 2016-17). It is mainly cultivated in Jodhpur, Barmer, Jalore, Nagaur, Churu, Jaipur, Sikar, Alwar and Jhunjhunu districts of Rajasthan. According to the producing production and productivity of pearl millet, is too much below than its production potential due to vary greatly with rainfall intensity and its distribution. Hence, our research effort should be diverted to remove the constraints that are responsible for its poor yield in Rajasthan.

\section{Materials and Methods}

The Experiment was conducted at Agronomy farm of S.K.N College of Agriculture, Jobner in plot no. 2B. The climate of this area is typically semi-arid characterized by the aridity of the atmosphere, scarcity of water with extremity of temperatures both during summer and winter. The analysis of experimental soil showed that experimental soil was loamy sand in texture with high infiltration rate $(22.46 \mathrm{~cm} / \mathrm{hr})$ and saturated hydraulic conductivity $10.20 \mathrm{~cm} / \mathrm{hr}$. The soil was low in organic carbon $(1.8 \mathrm{~g} / \mathrm{kg})$, low available nitrogen (128.34 kg N/ha) available phosphorus (15.23 $\mathrm{kg} \mathrm{P}_{2} \mathrm{O}_{5} / \mathrm{ha}$ ) and medium in available potassium (145.08 $\mathrm{kg} \mathrm{K}_{2} \mathrm{O} / \mathrm{ha}$ ). The soil was non saline with a reaction 8.2 In order to evaluate the fertility status and other physico-chemical properties of the soil samples were taken from $0-15 \mathrm{~cm}$ depth from five random spots of the experimental field prior to layout and representative composite soil sample was prepared by quantity measure of sampling together. It is apparent from data that soil of the experimental field was alkaline in reaction, poor in organic carbon, low in available nitrogen and phosphorus and medium in potassium. The experiment comprised with different combination of following factors treatment consisted of eight levels of nitrogen sources and two levels of bio-fertilizer for pearl millet. The details of the treatments are given as under. The experiment comprised eight treatments of sources of nitrogen Control, $50 \%$ RDN through urea+ $50 \%$ RDN through vermicompost, $50 \%$ RDN through urea+ $50 \%$ RDN through FYM, 75\% RDN through urea+ $25 \%$ RDN through vermicompost, $75 \%$ RDN through urea+ $25 \%$ RDN through FYM, $100 \%$ RDN through urea, 100\% RDN through vermicompost and $100 \%$ RDN through FYM and two treatments of biofertilizer (without inoculation and with Azotobacter) were applied to the pearlmillet var. RHB-173.FYM and vermicompost were applied 12@ tone $\mathrm{ha}^{-1}$ and 6@ tonne ha ${ }^{-1}$ respectively as per treatments 12 days before sowing and prior to sowing. Urea was applied half dose at the time of sowing and remaining half dose at flowering stage as per treatment. The seeds were treated with Azotobacter bacteria as per treatment in the following manner. About 125 $\mathrm{g}$ of jaggery was boiled in one liter water and then cooled. One packet of Azotobacter culture was mixed separately in required quantity of jaggery solution. The required seed was mixed thoroughly with the paste of culture as per treatment and allowed to dry in shade.

\section{Results and Discussion}

\section{Growth parameter}

Plant height of pearlmillet at 30 and 60 DAS and at harvest are presented in table 1. Plant height was increased progressively with 
advancement in age of the crop upto harvest, irrespective of the treatments $75 \%$ RDN through urea $+25 \%$ RDN through vermicompost showed higher plant height as compared to their other treatment at 30,60 DAS and at harvest. Application of $75 \%$ RDN through urea+25\% RDN through vermicompost, $50 \%$ RDN through urea $+50 \%$ RDN through vermicompost and 75\% RDN through ureat $25 \%$ RDN through FYM recorded a significant increment by $18.4,15.8$ and 13.3 per cent at 30 DAS, and 35.6, 31.8, and 26.7 per cent at 60 DAS and 37.9, 30.7, and 27.8 per cent at harvest over control, respectively.

Data (Table 1) further revealed that seed inoculation with Azotobacter significantly increased the plant height at all the growth stages in comparison to no inoculation. Seed inoculation with Azotobacterin pearlmillet recorded the maximum plant height indicating an increase of 8.8, 11.1, and 8.1 per cent over no inoculation, at 30 DAS, 60 DAS and at harvest, respectively. The data on dry matter production at 30 and 60 DAT and at harvest are presented in table 2. Dry matter production increased progressively with advancement in age of the crop up to harvest but the trend of dry matter accumulation varied at different stages of crop growth. Application of $75 \%$ RDN through urea+25\% RDN through vermicompost, 50\% RDN through urea $+50 \%$ RDN through vermicompost and $75 \%$ RDN through ureat 25\% RDN through FYM being indicating an enhancement of $36.2,30.9$ and 27.8 per cent at 30 DAS 47.2, 38.0, and 32.3 per cent at 60 DAS and 41.0, 31.9, and 28.8 per cent at harvest over control, respectively. Alone application of urea, FYM and vermicompost were also remained at par with each other and found significantly superior over control. Data further indicated that seed inoculation with Azotobacter in pearlmillet seed recorded significantly higher dry matter accumulation at all growth stages indicating an increment of 12.2, 9.2 and 9.1 per cent at 30 DAS, 60 DAS and at harvest over no inoculation, respectively. Results showed that application of integrated use of nitrogen significantly increased the growth attributes of pearlmillet like plant height, dry matter accumulation and total tillers per meter row length at different growth stages (Table 1 and 2). The maximum values of these parameters were observed with $75 \%$ RDN through urea $+25 \%$ RDN through vermicompost. Findings reported by previous workers also indicated that a suitable combination of nitrogen sources and manures maintain a long-term soil fertility and sustain high level of productivity. The reason for better growth and development under these treatments might be the increased availability of nutrients to plant initially through inorganic nitrogen source and then by organic manures like vermicompost and FYM matching to the need of crop throughout the growing season. Being a cereal crop, pearlmillet required nutrients throughout the growing season. The better growth in terms of plant height, dry matter accumulation and total tillers per metre were recorded due to application of $75 \%$ RDN through urea $+25 \%$ RDN through vermicompost than rest of the treatments. However, treatment 50\% RDB through urea $+50 \%$ RDN through vermicompost and $75 \%$ RDN through urea+ $25 \%$ RDN through FYM remained at par with each other. These results also corroborate the findings of Kathuria (1997), Meena et al., (2012) and Thumar et al., (2016) in pearlmillet.

It is the established fact that vermicompost improves the physical and biological properties of soil including supply of almost all the essential plant nutrients for the growth and development of plants. Vermicompost provides secondary elements like $\mathrm{Ca}, \mathrm{Mg}$, and $\mathrm{S}$ and fairly high amounts of micronutrients to the plants. It also increases CEC, water 
holding capacity and nitrogen availability in the soil. Thus, balanced nutrition due to release of macro and micro nutrients due to application of vermicompost and FYM under favorable environment might have helped in higher uptake of nutrients. This accelerated the growth of new tissues and development of new shoots that have ultimately increased the plant height and dry mater accumulation. The results of present investigation are in conformity with those of Thakral et al., (2000), Kumar and Gautam (2004), Parihar et al., (2012) and Thumar et al., (2016) in pearlmillet while Hashim et al., (2014) in Maize.

It is well known that nitrogen is the most indispensable nutrient in all the mineral nutrients for growth and development of plant as it is the basis of fundamental constituents of all living matter. It also plays an important role in plant metabolism by virtue of being a constituent of many essential compounds like amino acids, proteins, nucleic acids, enzymes, coenzymes, alkaloids and a number of hormones. These results also corroborate the findings of Narayan and Joshi (2000), Chaudhari et al., (2002) and Yadav and Beniwal (2003) in pearlmillet. The positive effect of nitrogen and phosphorus supplied through combinations of fertilizers with higher dose of manures on growth could be ascribed to its effectiveness in providing a balanced nutritional environment favorably both in rhizosphere and plant system. The overall improvement in crop growth under the influence of nitrogen and phosphorus fertilization and micro nutrients through combined application of nitrogen and manures could possibly be attributed to better development of plant growth and increased microbial activities due to better soil health. The results obtained in the present investigation are in close conformity with the finding of Khan et al., (2000) in pearlmillet, Nehra et al., (2001) in wheat, Patidar and
Mali (2004) in sorghum and Singh et al., (2005) in pearlmillet and Tripati and Kushwaha (2013) in pearlmillet.

\section{Yield attributes and yield}

The data pertaining to the effect of integrated nitrogen management on yield attributes and yield of pearlmillet are being presented in table 3 and 4

A reference to the data presented in table 3 revealed that numbers of effective tillers per meter row length, grain per ear head and test weight of pearlmillet were significantly increased by all the treatments of nitrogen and manure over control. Application of $75 \%$ RDN through urea+25\% RDN through vermicompost produced the highest number of effective tillers, grain ear head and test weight which indicated an improvement of $56.9,18.5$ and 30.6 per cent over control, $50 \%$ RDN through urea $+50 \%$ RDN through vermicompost, $50 \%$ RDN through urea $+50 \%$ RDN through FYM, 75\% RDN through urea+ $25 \%$ RDN through FYM, 100\% RDN through urea and $100 \%$ RDN through vermicompost, respectively. However, the application of $50 \%$ RDN through urea $+50 \%$ RDN through vermicompost were at par with $75 \%$ RDN through urea+ $25 \%$ RDN through FYM in respect to effective tillers of pearlmillet grain per ear head and test weight.

A perusal of data summarized in table 3 further reveals that seed inoculation of pearlmillet seeds with Azotobacter recorded significantly higher number of effective tillers per meter row length grain per ear head and test weight than uninoculated control. This microbial inoculant registered an increase of 16.2 per cent over control.

A perusal of the data in table 4 further revealed that application of $75 \%$ RDN through urea $+25 \%$ RDN through 
vermicompost was recorded the maximum stover $(6638 \mathrm{~kg} / \mathrm{ha})$, and grain yield $(2190$ $\mathrm{kg} / \mathrm{ha}$ ), which was significantly superior to rest of the treatment and indicated an increase of 49.5 per cent over control. Application of $50 \%$ RDN through urea $+50 \%$ RDN through FYM, 75\% RDN through urea $+25 \%$ RDN through FYM, 100\% RDN through urea, $100 \%$ RDN through vermicompost and 100\% RDN through FYM, improve the grain yield by $35.6,26.6,34.8,10.3,18.4$, and 2.0 per cent, respectively. Treatment $50 \%$ RDN through urea $+50 \%$ RDN through vermicompost and $75 \%$ RDN through urea+ 25\% RDN through FYM was at par with each other. Further results showed that significantly higher stover and grain yield $(1909 \mathrm{~kg} / \mathrm{ha})$ was recorded when seed of pearlmillet was inoculated with Azotobacter. The per cent increment due to seed inoculation was 11.1 and 11.9 over no inoculation.

Results presented in table 3 to 4 showed that yield attributes viz., number of effective tillers, number of grains per ear and test weight improved by application of $75 \%$ RDN through urea $+25 \%$ RDN through vermicompost as compared to other treatments. The dry matter accumulation and higher number of tillers recorded under these treatments due to greater availability of most of the macro and micro nutrients in appropriate amounts and balanced proportion that led to higher uptake of the nutrients.

Table.1 Effect of sources of nitrogen and biofertilizer on plant height $(\mathrm{cm})$ at different stages of pearl millet

\begin{tabular}{|c|c|c|c|}
\hline \multirow[t]{2}{*}{ Treatments } & \multicolumn{3}{|c|}{ Plant height (cm) } \\
\hline & 30 DAS & 60 DAS & At harvest \\
\hline \multicolumn{4}{|l|}{ Source of nitrogen } \\
\hline$S_{0}($ Control $)$ & 66.23 & 110.60 & 150.16 \\
\hline $\begin{array}{l}\mathrm{S}_{1}(\mathbf{5 0} \% \mathrm{RDN} \text { through urea }+\mathbf{5 0} \% \mathrm{RDN} \text { through } \\
\text { vermicompost) }\end{array}$ & 76.73 & 145.78 & 196.26 \\
\hline $\begin{array}{l}\mathrm{S}_{2}(50 \% \text { RDN through urea }+50 \% \text { RDN through } \\
\text { FYM) }\end{array}$ & 72.83 & 137.60 & 185.46 \\
\hline $\begin{array}{l}S_{3}(75 \% \text { RDN through urea }+25 \% \text { RDN through } \\
\text { vermicompost) }\end{array}$ & 78.43 & 150.03 & 207.08 \\
\hline $\begin{array}{l}S_{4}(75 \% \text { RDN through urea }+25 \% \text { RDN through } \\
\text { FYM) }\end{array}$ & 75.04 & 140.08 & 191.96 \\
\hline$S_{5}(100 \%$ RDN through urea) & 71.73 & 129.15 & 167.82 \\
\hline$S_{6}(100 \%$ RDN through vermicompost $)$ & 72.23 & 133.41 & 176.65 \\
\hline $\mathrm{S}_{7}(100 \%$ RDN through FYM & 70.63 & 124.86 & 159.01 \\
\hline SEm \pm & 1.13 & 3.24 & 5.16 \\
\hline $\mathrm{CD}(\mathbf{P}=\mathbf{0 . 0 5})$ & 3.26 & 9.35 & 14.89 \\
\hline \multicolumn{4}{|l|}{ Biofertilizer } \\
\hline $\mathbf{A}_{0}($ Control $)$ & 69.88 & 126.89 & 172.25 \\
\hline $\mathbf{A}_{1}$ (Azotobacter) & 76.08 & 140.99 & 186.35 \\
\hline SEm + & 2.26 & 1.62 & 2.58 \\
\hline $\mathrm{CD}(\mathrm{P}=\mathbf{0 . 0 5})$ & 6.51 & 4.67 & 7.45 \\
\hline
\end{tabular}


Table.2 Effect of sources of nitrogen and biofertilizer on dry matter accumulation (g per metre row length) at different stages of pearlmillet

\begin{tabular}{|c|c|c|c|}
\hline \multirow[t]{2}{*}{ Treatments } & \multicolumn{3}{|c|}{$\begin{array}{l}\text { Dry matter accumulation (g per } \\
\text { metre row length) }\end{array}$} \\
\hline & 30 DAS & 60 DAS & At harvest \\
\hline \multicolumn{4}{|l|}{ Source of nitrogen } \\
\hline$S_{0}($ Control $)$ & 95.71 & 140.46 & 237.50 \\
\hline$S_{1}(50 \%$ RDN through urea $+50 \%$ RDN through vermicompost) & 125.28 & 193.86 & 313.42 \\
\hline $\mathrm{S}_{2}(50 \%$ RDN through urea $+\mathbf{5 0 \%}$ RDN through FYM $)$ & 118.33 & 181.32 & 297.12 \\
\hline $\mathrm{S}_{3}(\mathbf{7 5} \% \mathrm{RDN}$ through urea $+25 \% \mathrm{RDN}$ through vermicompost $)$ & 130.39 & 206.77 & 335.00 \\
\hline$S_{4}(75 \%$ RDN through urea $+25 \%$ RDN through FYM) & 122.34 & 185.91 & 306.00 \\
\hline $\mathrm{S}_{5}(100 \% \mathrm{RDN}$ through urea) & 107.82 & 166.23 & 272.50 \\
\hline$S_{6}(100 \%$ RDN through vermicompost $)$ & 113.03 & 173.09 & 285.32 \\
\hline $\mathrm{S}_{7}(\mathbf{1 0 0 \%}$ RDN through FYM & 102.51 & 158.67 & 259.60 \\
\hline SEm \pm & 3.07 & 5.49 & 9.28 \\
\hline $\mathrm{CD}(\mathbf{P}=\mathbf{0 . 0 5})$ & 8.85 & 15.86 & 26.79 \\
\hline \multicolumn{4}{|l|}{ Biofertilizer } \\
\hline$A_{0}$ (Control) & 107.86 & 168.04 & 275.76 \\
\hline $\mathbf{A}_{1}$ (Azotobacter) & 120.99 & 183.54 & 300.86 \\
\hline SEm \pm & 1.53 & 2.75 & 4.64 \\
\hline $\mathrm{CD}(\mathbf{P}=\mathbf{0 . 0 5})$ & 4.43 & 7.93 & 13.40 \\
\hline
\end{tabular}

Table.3 Effect of sources of nitrogen and biofertilizer on yield attributes of pearlmillet

\begin{tabular}{|c|c|c|c|}
\hline Treatments & $\begin{array}{l}\text { Effective tillers } \\
\text { per meter row }\end{array}$ & $\begin{array}{l}\text { Grains per } \\
\text { ear head }\end{array}$ & $\begin{array}{l}\text { Test weight } \\
\text { (g) }\end{array}$ \\
\hline \multicolumn{4}{|l|}{ Source of nitrogen } \\
\hline$S_{0}($ Control $)$ & 18.10 & 1086 & 6.10 \\
\hline $\begin{array}{l}\mathrm{S}_{1}(\mathbf{5 0} \% \text { RDN through urea + 50\% RDN through } \\
\text { vermicompost) }\end{array}$ & 25.42 & 1287 & 7.35 \\
\hline$S_{2}(50 \%$ RDN through urea $+50 \%$ RDN through FYM) & 24.12 & 1256 & 7.26 \\
\hline $\begin{array}{l}S_{3}(75 \% R D N \text { through urea }+25 \% \text { RDN through } \\
\text { vermicompost) }\end{array}$ & 28.41 & 1399 & 7.97 \\
\hline$S_{4}(75 \%$ RDN through urea $+25 \%$ RDN through FYM) & 25.22 & 1277 & 7.23 \\
\hline $\mathrm{S}_{5}(100 \%$ RDN through urea $)$ & 21.81 & 1154 & 6.92 \\
\hline$S_{6}(100 \%$ RDN through vermicompost) & 23.01 & 1204 & 7.12 \\
\hline$S_{7}(100 \%$ RDN through FYM & 20.31 & 1104 & 6.68 \\
\hline SEm \pm & 0.74 & 38 & 0.21 \\
\hline $\mathrm{CD}(\overline{\mathbf{P}}=\mathbf{0 . 0 5})$ & 2.14 & 110 & 0.61 \\
\hline \multicolumn{4}{|l|}{ Biofertilizer } \\
\hline$A_{0}($ Control $)$ & 21.55 & 1191 & 6.74 \\
\hline $\mathbf{A}_{1}$ (Azotobacter) & 25.05 & 1250 & 7.41 \\
\hline SEm \pm & 0.37 & 19 & 0.11 \\
\hline $\mathrm{CD}(\overline{\mathbf{P}}=\mathbf{0 . 0 5})$ & 1.07 & 55 & 0.30 \\
\hline
\end{tabular}


Table.4 Effect of sources of nitrogen and biofertilizer on grain and stover yield of pearlmillet

\begin{tabular}{|c|c|c|}
\hline Treatments & $\begin{array}{l}\text { Grain yield } \\
\left(\mathrm{kg} \mathrm{ha}^{-1}\right)\end{array}$ & $\begin{array}{l}\text { Stover yield } \\
\left(\mathrm{kg} \mathrm{ha}^{-1}\right)\end{array}$ \\
\hline \multicolumn{3}{|l|}{ Source of nitrogen } \\
\hline$S_{0}($ Control $)$ & 1482 & 4438 \\
\hline $\begin{array}{l}\mathrm{S}_{1}(50 \% \mathrm{RDN} \text { through urea }+50 \% \mathrm{RDN} \text { through } \\
\text { vermicompost) }\end{array}$ & 2011 & 6022 \\
\hline $\begin{array}{l}S_{2}(50 \% \text { RDN through urea }+50 \% \text { RDN through } \\
\text { FYM) }\end{array}$ & 1877 & 5621 \\
\hline $\begin{array}{l}\mathrm{S}_{3}(75 \% \mathrm{RDN} \text { through urea }+25 \% \mathrm{RDN} \text { through } \\
\text { vermicompost) }\end{array}$ & 2190 & 6638 \\
\hline $\begin{array}{l}\mathrm{S}_{4}(75 \% \text { RDN through urea }+25 \% \text { RDN through } \\
\text { FYM) }\end{array}$ & 1999 & 5986 \\
\hline $\mathbf{S}_{5}(\mathbf{1 0 0} \%$ RDN through urea) & 1636 & 4899 \\
\hline$S_{6}(100 \%$ RDN through vermicompost) & 1756 & 5258 \\
\hline $\mathrm{S}_{7}(\mathbf{1 0 0 \%}$ RDN through FYM & 1513 & 4531 \\
\hline SEm \pm & 61 & 188 \\
\hline $\mathrm{CD}(\overline{\mathbf{P}}=\mathbf{0 . 0 5})$ & 177 & 543 \\
\hline \multicolumn{3}{|l|}{ Biofertilizer } \\
\hline$A_{0}($ Control $)$ & 1707 & 5121 \\
\hline $\mathrm{A}_{1}$ (Azotobacter) & 1909 & 5727 \\
\hline SEm \pm & 31 & 94 \\
\hline CD (P=0.05) & 88 & 272 \\
\hline
\end{tabular}

The increased growth provided greater site for photosynthesis and diversion of photosynthates towards sink (ear and grain). The beneficial effect on yield attributes might also be due to the increased supply of all the essential nutrients by vermicompost and FYM that might have resulted in higher manufacture of food and its subsequent partitioning towards sink. The findings of present investigation are supported by Khan et al., (2000) and Kumar and Gautam (2004) in pearlmillet Kumawat and Jat (2005) in barley Hasim et al., (2015) in maize and Divya et al., (2017) in pearlmillet.

Significantly higher grain yield was obtained by the application of $75 \%$ RDN through urea $+25 \%$ RDN through vermicompost as compared to other treatments while 50\% RDB through urea $+50 \%$ RDN through vermicompost and 75\% RDN through urea+ 25\% RDN through FYM were at par with each other (Table 4). The higher values of yield attributes like effective tillers per metre row length, number of grains per ear head, ear head length and test weight coupled with the higher crop dry matter observed with these treatments might have been the most probable reason of higher grain and stover yield. The increment in grain yield of pearlmillet with these treatments was also largely due to high harvest index that showed high partitioning of the plant assimilates towards the sink (Table 4). Since, application of $75 \%$ RDN through urea $+25 \%$ RDN through vermicompost significantly increased the growth parameters viz., plant height, number of tillers and dry matter accumulation per metre row length, the 
resultant effect of these parameters might have also produced higher stover yield. Since, biological yield is a sum of grain and stover yields, the improvement in these parameters as discussed above also enhanced the biological yield significantly due to these treatments. Significantly higher net returns achieved with the application of $75 \%$ RDN through urea $+25 \%$ RDN through vermicompost are directly correlated with the considerably higher grain and stover yields corresponding to these treatments. Slightly lower net returns recorded under the treatment involving $100 \%$ RDN through urea than the corresponding levels of FYM could be explained with the fact that vermicompost is comparatively costlier than FYM. Similar results were also obtained by Jayanthi et al., (2002 a) in pearlmillet hybrid Napier, Jain and Poonia (2003) in pearlmillet, Singh and Singh (2005) in wheat and Parihar et al., (2012) in pearlmillet, Patel et al.,(2014) in pearlmillet.

\section{References}

Chaudhari, A.C., Meena, N.L. and Jat, R.L. 2002. Effect of nitrogen and moisture conservation practices on growth and yield of rainfed pearlmillet. Annals of Agriculture Research, 23: 223-225.

Divya, G., Vani, K.P., Babu, S., and Suneetha Devi, K.B., 2017. Yield Attributes and yield of summer pearl millet as influenced by cultivars and integrated nutrient management. International Journal of Current Microbiology and Applied Sciences, 10: 1491-1495.

Jain, N.K., and Poonia, B.L. 2003. Integrated nutrient management in pearlmillet and optimizing fertilizer requirement in succeeding wheat. Crop Research, 26:62-66.

Jayanthi, C., Malarvizhi, P., Chinnusamy, C. and Mythili. S. 2002. A integrated nutrient management for Baja-hybrid
Napier system. Journal of Farming System Research and Development, 8: 10-14.

Khan,H., Jain, P.C. and Trivedi, S.K. 2000. Nutrient management in pearlmillet (Pennisetum glaucum L.) under rainfed condition. Indian Journal of Agronomy 45: 728-731.

Kumar, N. and Gautam, R.C. 2004. Effect of moisture conservation and nutrient management practices on growth and yield of pearlmillet under rainfed conditions. Indian Journal of Agronomy, 49: 182-185.

Kumawat, P.D. and Jat, N.L. 2005. Effect of organic manure and nitrogen fertilization on productivity of barley. Indian Journal of Agronomy, 50: 200202.

Meena, S., Jain, K. K., Prasad, D. and Ram, A. 2012. Effect of nitrogen on growth, yield and quality of fodder Pearlmillet (Pennisetum glaucum L.) cultivar under irrigated condition North -Western Rajasthan. Annals of Agriculture Research, 33:183-188.

Narayan, P. and joshi, N.L. 2000. Nutrient management of pearlmillet in arid region of Rajasthan. Fertilizer News, 75: $35-43$.

Nehra, A.S., Hooda, I.S. and Singh, K.P. 2001. Effect of integrated nutrient management on growth and yield of wheat. Indian Journal of Agronomy, 46: 112-117.

Patel, P.R., Patel, B.J., Vyas, K.G. and Yadav, B.L. 2014. Effect of integrated nitrogen management and bio fertilizer in kharif Pearlmillet (Pannisetum glaucum L.), Advances of Research Journal Crop Improvement, 5: 122-125.

Singh, R.C., Kumar, S., Kadian, V.S. and Singh, S.N. 2005. Effect of FYM and fertilizer along and their combination on yield of pearlmillet. Haryana Agriculture University Journal of 
Research, 35: 109-112.

Thakral, S.K., Kumar, S. and Singh, S. 2000.

Response of pearlmillet to organic manures and fertilizers under saline soil conditions Haryana Journal of Agronomy, 16: 76-78.

Thumar, C. M. and Dudha, M.S., 2016 Growth, yield attributes, yield and Economics of summer Pearlmillet
[Pennisetum glaucum L.] as influence by integrated nutrient management. International Journal of Agriculture Science, 59:3344-334.

Yadav, N.D. and Beniwal, R.K. 2003. Response of pearlmillet to $\mathrm{N}$ and FYM under rainfed condition. Arid zone Research Association of India, 5: 276279.

\section{How to cite this article:}

Poonam Kumari Yadav, Rajhans Verma, J.K. Bamboriya, Suresh Yadav and Rajesh C. Jeeterwal. 2019. Response of Pearl Millet [Pennisetum glaucum L. (R. Br.)] to Integrated Nitrogen Management. Int.J.Curr.Microbiol.App.Sci. 8(02): 429-437. doi: https://doi.org/10.20546/ijcmas.2019.802.048 